\title{
French Narrative Discourse and its Translation in Indonesian
}

\author{
Sajarwa \\ Faculty of Cultural Sciences \\ Universitas Gadjah Mada, Yogyakarta, Indonesia \\ sajarwa@ugm.ac.id
}

\begin{abstract}
The main issue in translation is the equivalence between the source text (ST) and the Target Text (TT). This equivalence relates to the message. Equivalence is both a negotiation and transaction. This is also present in the translation of narrative discourse of novels. There are two types of narrative discourse, namely discours and histoire. The distinctions between the two types of discourse take advantage of linguistic markers. This research revealed the translation of both types of narrative discourse from French novels, as the source texts, into Indonesian translation novels, as the target texts. The comparative-descriptive method was used in analyzing the data. The results of this study indicate that in the French novels the narrator uses a proper noun or a pronoun of non generic subject in the narrative discourse of discours, whereas in the narrative discourse of histoire, the narrator uses pronoun on. In comparison, in the Indonesian translations, in the narrative discourse of discours the narrator uses a proper noun, pronoun, and pronoun repetition, whereas in the narrative discourse of histoire the narrator uses passive forms.
\end{abstract}

Keywords—translation; discours; histoire; proper noun; pronoun-repetition; passive

\section{INTRODUCTION}

The narrative discourse contains the sequence of events, or if the narrative discourse is fictional then it contains a sequence of fictional events (Rimmon-Kenan, 1983, pp. 15). Narrative discourse has certain characteristics. Firstly, the narrative discourse can be seen in its character-oriented propositions. Secondly, narrative discourse can be seen in propositions that have a chronological relationship or time series relationship. Thirdly, the narrative discourse can be seen in its structure called the stimulus-response structure. That is a proposition that expresses the 'stimulation' of the action of a character and there is a proposition expressing a 'response' to that stimulus; and Fourthly, narrative discourses can be seen in various forms, such as short stories, novels, stories, histoires, and tales (in Sumadi, 1998). Elements that are considered important in the narrative discourse, in addition to the subjects are also the subjects' actions (Prop in Renkema, 1993, pp. 118-120).

Associated with the action, there is a section of action or events that are highlighted or put as the foreground. It is the narrative section which presents the main parts that fit the purpose of the story, and there is also the background, which is the narrative section that strengthens or comment on the purpose of the story (Hopper, 1979, p. 280). The setting in French discourse is marked by tenses (Sajarwa,
2013, pp. 31-36). In addition to the setting, in the narrative discourse there is also a style of storytelling consisting of two types, which are discours and histoire (Benveniste, 1966, pp. 250-337 and Hoed, 1992, pp. 73-74). The discours style occurs when it is emphasized on the relationship between the sender (P1) and the recipient (P2). What is important in this discours type is "I tell you or I say to you". As for the histoire style of storytelling, it emphasizes on the context or reference (r) so that it seems as if the sender or speaker is being the background or disappear to accentuate the story (Hoed, 1992, p. 74). In other words, if the speaker or the narrator uses the discours type then the subject is used, but if the narrator uses a type of histoire, he/she highlights the event and, thus, weakens the subject.

According to Nida and Taber (1964, p. 166) translation is an attempt to recount the message in the source text (ST) into the target text (TT) by prioritizing the correspondence of the message and then the formal alignment or the style of language. Therefore, the main priority is the revelation of the message in the Target Language. Basically the main problem in translation is how to find translation equivalence in TT (Catford 1965, p. 21). When a translator searches for the equivalence of the message, there are many things to consider. For this matter, Wills (1992, p. 3) suggests the three understandings, which are syntactic, semantic, and pragmatic understandings. This paper examines the translation of narrative discourse, especially storytelling style, of French novels into Indonesian. The method used is descriptive-comparative method.

\section{RESULT AND DISCUSSION}

\section{A. Translation of Narrative Discourse of Discours}

In the narrative discourse of discours storytelling style the narrator uses a subject, which can be a proper name and pronoun. Pronouns and proper names in discourse also serve as a tool of the continuity of the topic (Sajarwa, 2015, pp. 25-53). The following are the types of subjects in the narrative discourse of French as well as their translation in Indonesian. 
(1) Lamia se serait très certainement accommodée d'un mari moins terne. Elle qui était si gaie, espiègle, primesautière, chaque fois qu'elle se faisait remarquer en public par un mot d'esprit, un petit rire, chaque fois qu'elle fredonnait une chanson, Gérios était là, à la fixer, sourcils froncés, renfrogné, la mine inquiète. Alors elle se taisait. (RT, 29)

Sebetulnya Lamia jelas lebih cocok dengan suami yang tidak terlalu murung. Ia begitu riang, ceria, lincah, tutur katanya bebas, setiap kali menarik perhatian orang banyak dengan gurauannya, tawa yang lepas, setiap kali ia bersenandung. Gérios berdiri di dekatnya, menatapnya, alisnya dikernyitkan, murung, wajah khawatir. Maka perempuan itu diam. (CT, 14)

(Lamia would certainly be more suitable with a less dull husband. She was so cheerful, happy, energetic, speaks whatever in her mind, every time she attracted lots of people with her jokes, her laugh, every time she hummed a song. Gerios was standing there next to her, looking at her, frowning, gloomy, with worried look. So, that woman went silent. (RT, 29))

The discourse above shows that the character Lamia is replaced by a pronoun elle (her) and translated as Lamia and ia (her) in Indonesian. However, in the next translation sentence there is a change of strategy that is from the pronoun strategy to the lexical equivalent strategy, peremuan itu (the woman). This is due to the emergence of another proper name other than Lamia that is Gerios which is masculine. If pronoun ia (she/he) is used, it will cause a confusion for the readers about the reference of the pronoun ia (he/she), as whether it is referring to Lamia or Gerios. In discourse (2) bellow, pronoun il 'dia' (he) is continued with a demonstrative pronounce, while in Indonesian that demonstrative pronoun is translated into ia (he/she).

(2) Vendredi savait défricher, labourer, semer, herser, repiquer, sarcler, faucher, moissonner, battre, moudre, pétrir, et cuir le pain. Il savait traire les chèvres, faire du fromage, ramasser les oeufs de tortue, en faire une omelette, raccomoder les vêtements de Robinson et cirer ses bottes. C'était devenu un serviteur modèle. (VVS:68)

Vendredi dapat membabat, mengerjakan ladang, menabur benih, membajak, menanam, menggarpu, menggunakan arit, menuai, menumbuk padi, membanting adonan dan membakar roti. Ia dapat memerah susu kambing, membuat keju, memungut telor kura-kura laut, membuat dadar telor itu, menjerumat baju Robinson dan menyemir sepatunya. Ia benar-benar menjadi pelayan teladan. (KL: 64)
(Vendredi knew how to chop down, plow, sow, harrow, plant, rake, mow, harvest, pound the rice, grind, knead the dough, and baking the bread. He knew how to milk goats, make cheese, collect turtle eggs, make an omelet, sewing Robinson's clothes and wax his boots. He had become a model servant. (VVS: 68))

Demonstrative pronoun is a pronoun that is demonstrative. The demonstrative meaning refers to something with a clear identity or has been appointed. In relation to the notion of clear or appointed, it consists of three types, which are l'actualisation, la monstration, and la situation (Charaudeau, 1992, p. 215). l'actualisation is something or a designated noun that exists in the text or is intralingual. La monstration describes something that is clearly categorized because it is present in the speech with a position close to the speaker so that it can be pointed at with a finger or can be even held. La situation relates to space and time during a speech. La situation consists of two types, which are in the speech that includes the speaker (locuteurinterlocuteur) and outside of the speech (hors interlocution).

In discourse (3) below the name of the subjects, Roukoz and Tanios, are mentioned repeatedly because in the discourse there is a name other than theirs. However, in discourse (4) it is different, in the French's ST the pronoun elles 'mereka' (they.them) is used, whereas in the Indonesian TT the form of iteration is used, for example kambing-kambing itu (those goats).

(3) Dans le visage de Roukoz, Tanios ne parvenait plus à voir que ces traces de vérole qui se creusaient encore, comme des puits à vermine. Il y eut un moment de silence. Roukoz respira une bouffée de son narguilé. Tanios vit les braises rougir, puis s'assombrir. (RT, 160)

Pada wajah Roukoz, yang terlihat di mata Tanios hanyalah noda-noda bekas cacar yang berlubanglubang dalam seperti sumur kutu. Saat itu hening sebentar. Roukoz menghembuskan asap pipanya. Tanios melihat tembakaunya memerah, lalu padam lagi. (CT, 140)

(On Roukoz's face, Tanios could only see those scars from chicken pox that were so deep like vermin wells. There was a moment of silence. Roukoz took a breath of his narghile. Tanios saw the embers blush, then darken. (RT, 160))

(4) Les chèvres que Robinson avait domestiquées et enfermées dans des enclos étaient retournées à l'état sauvage. Mais comme presque toutes les bêtes qui vivent en liberté, elles s'étaient organisées en groupes. (VVS, 117)

Kambing-kambing betina yang telah dijinakkan Robinson dari kurungan di dalam kandang telah kembali ke kehidupan liar. Namun seperti hampir 
semua binatang yang hidup bebas, kambing-kambing itu hidup berkelompok-kelompok. (KL, 111)

(The female goats that Robinson had domesticated and locked up in pens had returned to the wild. But like most animals that live in freedom, those were organized in groups. (VVS, 117))

In the following discourse, the subject in the pronoun form is followed by a zero. Halliday and Ruquaiya Hasan assert that the zero itself creates an empty space and this can be equated with a zero substitution because the speaker does not fill that empty space with words (1976, p. 143). In the Indonesian translation, the zero is also translated into zero in discourse (5) and the pronoun dia (he/she). This happens because the events in discourse (5) are successive events and end with an event that is not part of previous events. In other words, the last event is separate from the previous event.

(5) Souvent elle s'obstinait à ne pas sortir puis Ø suffoquait, $\varnothing$ ouvrait les fenêtres, $\varnothing$ s'habillait en robe légère. $(\mathrm{MB}, 102)$.

Acapkali ia berkeras hati tidak mau keluar, lalu karena sesak nafasnya membuka jendela. Dia mengenakan gaun tipis. (NB, 83)

(She often insists on not going out, and then because she is suffocated, she opened the windows. She dressed in a light dress. (MB, 102).)

\section{B. Translation of Narrative Discourse of Histoire}

In French discourse pronoun on is a personal indefinite pronoun and is neutral, both in types and quantities. Pronoun on is used when the subject is generic. In the narrative discourse pronoun on is used as a storytelling tool to accentuate the story or narration and to make the subject disappear. Meanwhile, in the Indonesian translation the generic nouns are used as shown in example (6) below. However, if the pronoun on refers to specific or special nouns then the translations also use pronouns, for example mereka (they/them), which in the previous sentences pronouns ces hommes 'mereka' (they/them) happened to be used in discourse (7). See examples (6) and (7) below.

(6) On raconte qu'avant de mourir un homme revoit souvent tout son passé étalé devant lui comme un panorama. (VVS, 138)

Orang mengatakan bahwa sebelum meninggal, manusia sering melihat seluruh masa lampaunya terbentang di hadapannya bagaikan panorama. $(\mathrm{KL}, 131)$

(Someone said that before dying a man often sees all his past spread before him like a panorama. (VVS, 138))
(7) En rentrant chez eux, plus tard dans la journée, ces hommes diraient à leurs épouses : «ce matin, j'ai vu la main du cheikh. » Non pas: «J'ai baissé la main...». Cela, on le faisait, certes, et en public, mais on avait pudeur à le dire. $(\mathrm{RT}, 18)$

Sesampai di rumah, menjelang petang, mereka menyampaikan kepada istri masing-masing, "Pagi tadi aku melihat tangan cheikh." Bukan: "Aku mencium tangan...". Itu memang mereka lakukan, dan di depan umum, tetapi mereka merasa tidak pantas mengatakannya demikian. $(\mathrm{CT}, 13)$

(On returning home, later in the day, they would say to their wives, "This morning, I saw the sheikh's hand. Not: "I kiss the hand of...". They certainly do this in public, but they had the modesty to say it. (RT, 18))

This is in contrast with discourse (8) and (9) below. In these sections pronoun on is not equally translated in Indonesian. Pronoun on is translated into the passive ter- in discourse (8) and the passive di- in discourse (9). Such a pronoun on is used as a storytelling tool to accentuate the story or tale/event, making the subject disappear or weaken the subject (state of affair). Structurally, the construction of French sentences using pronoun on is formally active but meant for passive.

(8) On ne voyait pas la figure cachée dans l'un des bras replié, mais le corps brun et nu ressemblait à Vendredi. (VVS, 99)

Tak terlihat wajah yang tersembunyi dalam lengan yang dilipat, namu badan yang coklat dan telanjang mirip Vendredi. (KL, 95)

(The figure hidden in one of the folded arms could not be seen, but the bare brown body looked like Vendredi's. (VVS, 99))

(9) On est ici sur les confins de la Normandie, de la Picardie et de ile-de-France, contre bâtarde où le langage est sans accentuation, comme le paysage sans caractère. C'est là que l'on fait les pires fromages de culture y est coûteuse, parce qu'il faut beaucoup de fumier pour engraisser ces terres friables pleines de sable et de cailloux (MB, 108) Di sinilah perbatasan negeri-negeri Normandie, Picardie dan Ile-de-France, sebuah tanah blaster, yang bahasanya tak bertekanan sebagaimana juga tamasyanya tak berwatak. Di sinilah dibuat keju Neufchatel yang paling tidak enak dari seluruh arondisemen. Bercocok tanam pun besar biayanya karena banyaknya pupuk yang diperlukan untuk merabuki tanahnya yang gampang remuk penuh pasir dan batu kerikil itu. (NB, 86)

(We are here on the border of Normandy, Picardy 
and Ile-de-France, a mulatto land, where the language is without accentuation and the landscape is without character. This is where the worst Neufchatel cheese in all arrondissement is made. Agriculture also spends a lot of money because it takes a lot of fertilizer for this friable land that full of sand and pebbles. (MB, 108)).

The use of pronoun on in (8) and (9) is related to focalization. Focalizations are those related to the narrator's perspective that includes the narrator and the object being told (Bal, 1992, p. 131). Genette (in Guillemette, 2006) divides the way of storytelling in two types, which are heterodiegetic (the absence of narrator) and homodiegetic (the narrator is present as a character in the story). By borrowing the term from Charaudeau (1992, p. 775) the first type is categorized as an external point of view while the second type is an internal point of view. Bal (1992, p. 31) divides the focalizations into the focalizator/subject and the focalized object. Therefore, the pronoun on is used as a storytelling tool to accentuate the story or tale and to make the subject disappear or focalized.

\section{CONCLUSION}

From the above description it can be concluded that the discours narrative discourse of the French that uses proper names or personal pronouns is translated into Indonesian as (i) proper names or personal pronouns if there is no interruption or other names emerge, (ii) lexical equivalence when interrupted, (iii) repetition if it is a non-human name. Meanwhile, in successive events the personal pronouns followed by zero are translated into Indonesian as pronouns and zero. However, if the zero in a series of successive events is then followed by an event that is not a part of the series, it is translated into Indonesian personal pronouns. In the the translation of the histoire narrative discourse, pronoun on in French that is generic is translated into Indonesian generic noun, which are person/proper name and personal pronoun, while the pronoun on as a tool to accentuate a story is translated into a passive forms of $\boldsymbol{d i}$ - or ter- in Indonesian.

\section{References}

Bal, M. (1992). Pengantar ilmu sastra (Dick Hartoko, trans.). Jakarta:Gramedia Pustaka Utama.

Benveniste, E. (1966). Problèmes de lingustique generale I Paris: Gallimard.

Catford, J.C. (1965). A linguistic theory of translation. London: Oxford University Press.

Charaudeau, P. (1992). Grammaire du sens et de l'Expression. Paris: Hachette.

Halliday, M.A.K. dan Ruqaiya Hasan. (1976). Cohesion in English. London: Longman.

Hoed, Benny H. (1992). Kala dalam novel: fungsi dan penerjemahannya. Yogyakarta: Gadjah Mada.
Hopper, P.J. (1979). Aspect and foregrounding discourse. In Talmy Givon (ed.) Syntax and semantics, 12, 213-241. New York: Academic Press.

Renkema, Jan. (1993). Discourse studies: introductory textbook. Amsterdam/Philadelphia: John Benjamins Publishing Company.

Rimmon-Kenan, Shlomith. (1983). Naratif fiction: contemporary poetics. London dan New York: Methuen.

Sajarwa. (2013). Pelataran dalam wacana bahasa Prancis. Humaniora, II, 31-36.

. (2015). Topik wacana bahasa prancis dan penerjemahannya dalam bahasa Indonesia (Unpublished doctoral dissertation). Universitas Gadjah Mada, Yogyakarta.

Sumadi. (1998). Kesatuan topik dalam wacana narasi bahasa Jawa (Laporan Penelitian). Balai Bahasa Yogyakarta.

Wills, Wolfram. (1992). Padanan terjemahan. In Sepuluh makalah mengenai penerjemahan oleh Kentjanawati Gunawan. Jakarta: Rebia Indah Prakasa.

Flaubert, Gustave. (1972). Madame Bovary (MB). Paris: Gallimard. diterjemahkan Nyonya Bovary $(N B)$ oleh Winarsih Arifin diterbitkan oleh PT Dunia Pustaka Jaya tahun 1990. Maalout, Amin. 1993.

Le Rocher de Tanios (RT). Grasser \& Fasqulle. diterjemahkan Cadas Tanios (CT) oleh Ida Sundari Husen diterbitkan oleh Yayasan Obor Indonesia tahun 1999.

Tournier, Michel. (1971). Vendredi ou la vie sauvage (VVS) .Paris: Gallimard diterjemahkan Kehidupan Liar (KL) oleh Ida Sundari Husen diterbitkan Pustaka Jaya tahun 1992. 